\title{
A REVIEW OF WATER QUALITY POLICIES IN RELATION TO PUBLIC GOOD BENEFITS AND COMMUNITY ENGAGEMENT IN RURAL IRELAND
}

\author{
Karen Daly ${ }^{1}$, Marion Breuil ${ }^{2}$, Cathal Buckley, Cathal O' Donoghue, \\ Mary Ryan, Catherine Seale ${ }^{3}$
}

\footnotetext{
${ }^{1}$ Karen Daly, Environment Soils and Land Use Department, Teagasc, Johnstown Castle, Wexford, Ireland; e-mail: Karen.Daly@teagasc.ie

2 Marion Breuil, VetAgro Sup, Campus Agronomique de Clermont-Ferrand, 89 Avenue de l'Europe - BP 35, 63370 Lempdes, France

${ }^{3}$ Cathal Buckley, Cathal O’Donoghue, Mary Ryan, Catherine Seale, Rural Economy and Development, Teagasc, Mellows Campus, Athenry, Galway, Ireland; e-mails: Cathal.Buckley@teagasc.ie, Cathal.ODonaghue@teagasca.ie, Mary.Ryan@teagasc.ie; Catherine.seale@open.ac.uk
} 
Abstract: This paper examines current recreational water use in the rural landscape in Ireland and reviews current EU policies and national regulations aimed at protecting water quality and the wider environment under agri-environmental schemes. Specifically, we review policy instruments that protect water for recreational use, their impacts and the challenges they pose for rural development against current requirements to increase public awareness and participation. In Ireland, there is limited experience in public participation in water quality protection and restoration and we highlight how this can be addressed by focussing on the specific contribution of water quality in rural areas in relation to the provision of recreational ecosystem services. These services provide the infrastructure for much of Ireland's rural tourism sector. In this context, emerging participatory approaches to policy implementation are also assessed as national and local government prioritise community engagement for the second cycle under the EU Water Framework Directive (WFD).

Key words: agriculture, nutrients, water quality, participation, benefits

\section{Introduction}

As an island member state Ireland has the advantage of abundant and varied coastal and inland fresh water systems set within a diverse physical landscape of upland and lowland rivers and lakes. An estimated $3171 \mathrm{~km}$ of coastline frames a predominantly rural landscape which is comprised mainly of agricultural holdings interspersed with forests in elevated and marginal areas. Within this landscape mosaic, $13,200 \mathrm{~km}$ of river and some 12,000 lakes provide a range of ecosystem services. Aylward et al. (2007) categorise fresh water ecosystem services as provisional (drinking, domestic, industrial and agricultural use), regulatory (buffering flood flow, erosion control and natural filtration) and cultural services which include water for recreational use and tourism. A 2007 survey conducted by the Irish tourism body (Fáilte Ireland, 2007) ${ }^{4}$ reported $72 \%$ of visitors perceived Ireland as an environmentally clean destination, and water for recreational use is an important component in Ireland's tourism sector with significant economic benefits. A visitor's attitude survey conducted in 2007 revealed that $32 \%$ of holidaymakers view Irish coastal waters as clean and safe, and $45 \%$ agreed that Irish rivers and lakes are clean and unpolluted.

However, the reality of water quality in Ireland is somewhat better than the perception and attitudes of its visitors in the 2007 survey and the most recent water quality reports indicate that $73 \%$ of river channel length in high or good condition, showing an improvement of $4 \%$ on previous monitoring records. Incorporated in Ireland's Tourism Product Development Strategy 2007-2013 under the National Development Plan, is investment in water infrastructure such as moorings, jetties and water sports centres for both domestic and visitor water recreational use. Securing both the economic sustainability of Ireland's tourism sector and the viability of Irish waters for recreational use will rely on ensuring that these water bodies meet environmental quality standards and targets set in the EU Water Framework Directive for the protection of waters. Identifying both the benefits supplied to society by water bodies and the drivers of water quality change will be central to developing sustainable management strategies for improvement and protection. However, this will require participation from stakeholders in all sectors and a degree of integrated thinking and strategy.

Using Ireland as a case study, this paper discusses the role of water for recreational use in the rural landscape and in the context of the pressures on water quality and the policy instruments and conservation measures that protect them. The main water body types featured in this study include freshwater rivers and lakes, in addition to transitional and coastal waters. The contribution of water quality and usage in rural areas is examined specifically in relation to the provision of recreational ecosystem services which provides the infrastructure for much of Ireland's rural

\footnotetext{
${ }^{4}$ http://www.failteireland.ie/Research-Insights.aspx
} 
tourism sector. In this context, emerging participatory approaches to policy implementation are also assessed.

\section{Context}

\section{Agricultural and Rural Development policy}

Of the total land area in Ireland (6.9 million ha), $64 \%$ is used for agricultural production with approximately $11 \%$ used for forestry. Agriculture in Ireland devotes $91 \%$ of land to grass based systems (silage, hay and pasture) with approximately $9 \%$ devoted to arable crop production. Farming practice can impact on the natural environment and is a recognised pressure on water quality, air quality and the preservation of habitats and protected species. However, this impact can range in scale and intensity and varies with farming practice (Roberts et al., 2017). The landscape and biophysical setting within which farmers operate can also contribute to the environmental impact. For example, the combination of soils and climate can influence nutrient, pesticide and contaminant losses from land to aquatic systems (Roberts et al., 2016; Daly et al., 2012., Mellander et al., 2012). Assessing the environmental impact of agriculture is a complex process that requires awareness of management practices within particular landscape settings. This is why the farmer's role in managing agricultural impacts is now formally recognised in agri-environmental policy (Mills et al., 2013).

Agricultural production in Ireland operates under the EU regulatory landscape known to be particularly complex (Barnes et al., 2013). EU rural land use in particular, is dominated by the various policies implemented under the Common Agricultural Policy (CAP) (Hart et al., 2012; Hodge et al., 2015). Agri-environmental schemes and cross compliance are reported as the current components of the CAP that are most explicitly targeted at improving the environmental impacts of agricultural practice (Bartolini et al., 2012). Public authorities seek to influence the decision making process of farmers in terms of how they use their land and other resources under their control (Povellato and Scorzelli, 2006).

Cross compliance emerged with the enactment of EC Regulation 1782/2003. The policy obliges all farmers in receipt of compensation under the Basic Payment Scheme (BPS) to abide by certain statutory management requirements and conditions of good environmental and agricultural condition (Kristensen and Primdahl, 2004). Cross compliance is considered as a baseline against which agri-environmental scheme prescriptions and payments are identified and justified (Bartolini et al., 2012).

The policy of cross compliance is administrated by an inspection process with farmers liable for financial penalties if non-compliance is determined by enforcement authorities. Two types of inspections are progressed: eligibility checks (related to the area claimed for payment) and cross compliance checks (to determine recipient compliance with Statutory Management Requirements $\left(\mathrm{SMRs}^{5}\right.$ ) and Good Agricultural and Environmental Condition (GAEC) regulations.

Conversely and notwithstanding the range of agri-environmental initiatives that have been implemented under the CAP, environmental issues pertaining to unsustainable intensive agricultural practices and concurrent land abandonment remain (Crowley, 2003; Boccaccio et al., 2009; Stoate et al., 2009; Hodge et al., 2015). Furthermore, from an economic sustainability perspective, it is suggested that meeting the higher environmental standards of EU production may be affecting the competitiveness of EU agricultural products on the world market (Menghi et al., 2008). Furthermore from a social perspective, it is observable that some farmers experience difficulties with the application of cross compliance policy (Seale, 2014)

The expenditure on the Common Agricultural Policy (CAP) is about $39 \%$ of the EU budget in $2014^{6}$, and there is increasing pressure to demonstrate the value-for-money of this considerable investment by the European taxpayer. While the objectives of the CAP relate largely to economic sustainability, the wider rural development objectives of the Rural Development Programme (RDP) of the CAP specifically support social and environmental sustainability in rural areas. These

\footnotetext{
${ }^{5}$ Nitrates Directive

${ }^{6}$ http://ec.europa.eu/agriculture/cap-post-2013/graphs/graph1_en.pdf
} 
objectives increasingly call for participatory approaches to improve quality of life and community engagement objectives in rural areas. Many of these objectives specifically support non-market or ecosystem services such as landscape, recreation and rural tourism. The role and function of good water quality in the rural community in terms of clean supply and the protection and support of sensitive species is now integrated into new schemes launched under the CAP. For example, in Ireland new agri-environmental schemes aim to promote agricultural production that is compatible with good water quality. Priority access to this scheme is given to the farming community living in areas with pristine water quality or high ecological status waterbodies. The protection of sensitive waterbodies and the prioritisation of farmers within these catchments, marks a departure from previous entry criteria into schemes under CAP for Ireland. This now demands a greater awareness by farmers of the water quality in their catchments and engagement with publicly available water quality monitoring data to support their case for priority access to these schemes. The inclusion water quality protection as an objective in agrienvironmental schemes is driven largely by water quality targets set at EU level, under policy instruments such as the WFD.

\section{Water quality policy}

The WFD came into force in $2000(2000 / 60 / E C)^{7}$ as the most comprehensive piece of water quality legislation aimed at improving water quality across Europe. The WFD provides a legal framework to protect and restore clean water and to ensure its long-term, sustainable use. This unique policy instrument aims to protect all categories of water body - river, lake, groundwater, and transitional and coastal waters, under a single piece of legislation and with the specific objectives of maintaining pristine and good water quality where it exists, and achieving good status for all waters. The key concept underlying the WFD is integration not just of existing water legislation (Nitrates Directive, Urban Wastewater Treatment Directive) but of water uses, function and values into a common policy framework, which includes water for social good. The integration of natural resource use and social good policies such as Habitats, Birds, Bathing Water, Floods, Urban Waste Water and Nitrates Directive is an integral part of ensuring good water quality in the rural environment.

The main areas of concern in relation to water supply are:

- Wastewater disposal

- Agriculture

- Agri-industry

- Amenity, recreation, bathing and angling

- Tourism

- Water regulation - flood prevention and

- Economic development.

The WFD provides a number of initiatives aimed at protecting the economic and social value of water in the rural landscape. Member states are required to draft River Basin Management Plans (RBMP) and to engage stakeholders in their implementation to ensure that water quality is protected, which will add to the tourism value and recreational use of Irish waters. Water Policy Regulations place new obligations on the Irish Environmental Protection Agency (EPA) in coordinating the catchment management and public participation elements of the WFD. As Ireland is now entering a second cycle of RBMPs (2015-2021) using three tiers of governance, namely, national and oversight, national technical implementation and reporting, and finally, regional implementation via water networks. Since January 2016, Ireland has been delineated into 46 WFD catchments for the purposes of river basin management planning which have been further subdivided into 583 subcatchments as the main reference data and building block for the characterisation and the development of programmes of measures under WFD (Figure 1). The subcatchment scale of $100-200 \mathrm{~km}^{2}$ has been selected by Ireland's EPA and the most appropriate scale to engage local communities to participate in improving and protecting water

\footnotetext{
7 http://ec.europa.eu/health/endocrine_disruptors/docs/wfd_200060ec_directive_en.pdf
} 
quality (EPA, pers. comm. 2016). In some cases, national and local authorities are now focussing their resources on engagement with local communities.

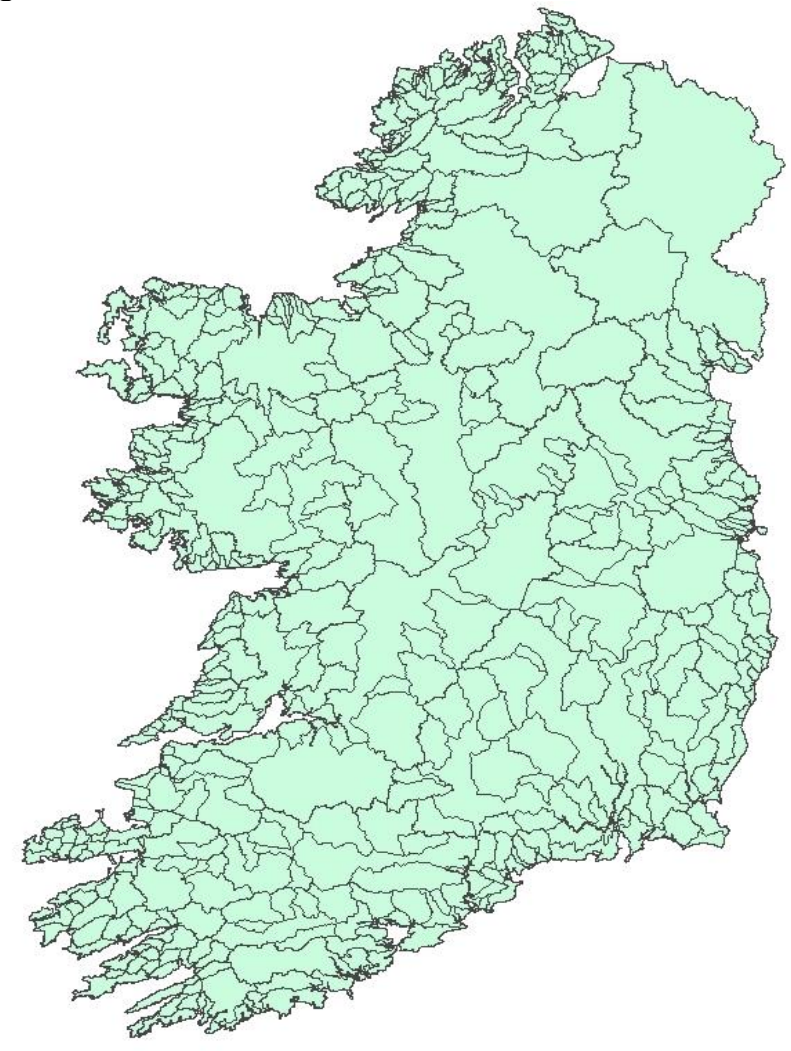

Fig 1. National WFD sub-catchments for use in River Basin Management Planning 2015-2021 (Source: EPA ${ }^{8}$ ).

\section{Protecting water quality for recreational use: current policy instruments and impacts}

Although water quality is generally good in Ireland, compared to other EU member states, the Irish EPA cites eutrophication or nutrient enrichment of surface and coastal waters as the largest threat to improving water quality in Ireland and meeting water quality targets under WFD. The target improvement of $13.6 \%$ from the baseline in 2009 to 2015 has not been reached and the significant challenge of reducing agricultural and municipal sources of pollution remains.

Enshrined in WFD is the concept of integrated catchment management and the process of implementing measures relies heavily on public consultation and awareness alongside stakeholder engagement and the input of communities at local level. However, measures need to be cost-effective and the Directive calls for a consideration of all the benefits as well as costs of improvements to ecological status in catchment management plans. Investment decisions are guided by cost recovery, cost-effectiveness criteria and the polluter pays principle. Identifying both the benefits supplied to society by water bodies and determining the major drivers of water quality will be key in developing sustainable management strategies aimed at meeting requirements under the WFD.

\section{Pressures on water quality}

There is a general conclusion from the existing literature that land use has a significant effect on river water quality (Woli et al., 2008; Varanka and Luoto, 2012). Under the WFD, Agriculture is recognised as a pressure on water quality, specifically nutrient enrichment of surface and groundwaters from agricultural sources. Nitrogen and phosphorus from animal and chemical sources when used in excess of crop demands can be transported to water bodies via hydrological pathways in soils causing eutrophication and nutrient enrichment.

\footnotetext{
${ }^{8}$ http://www.epa.ie/water/watmg/wfd
} 
In Ireland, the main threat to surface water quality is nutrient enrichment from agricultural and municipal sources. In Ireland's rural environment, agriculture as a pressure on water quality is addressed in existing policy instruments designed to abate nutrient enrichment of surface and ground waters. The Nitrates Directive (91/676/EEC) was established in 1991 to protect water quality from agricultural sources namely nitrogen and phosphorus. Transposing this complex legislation into Irish law has introduced a number of Statutory Instruments aimed at protecting water quality in the rural landscape, chief among which is SI 31 of 2014, Good Agricultural Practice $^{9}$ which sets limits on known pressures such as nutrient use in agriculture to protect against eutrophication of surface and groundwater from agricultural sources.

The main action points in this current legislation centre on restricting stocking rates and limiting nutrient use to meet crop demands. These regulations have resulted in reduced fertiliser use and increase resource efficiencies on Irish farms. For nutrients such as phosphorus, regulating it's use on farms under the Nitrates Directive have seen a national decline in soil phosphorus concentrations observed between 2008 and 2014 (Murphy et al., 2014). In conjunction with reduced $P$ use and better on-farm resource efficiency, recent reports from EPA have recorded reductions in surface water phosphate concentrations with river monitoring sites recording higher level of compliance with the Environmental Quality Standards for phosphorus ${ }^{10}$. Current water quality data for the period 2010-2012 in Ireland indicate that of 73\% of total channel length surveyed was designated as Class A or 'Unpolluted' condition based on the Irish Environmental Protection Agency (EPA) classification. Furthermore approximately $75 \%$ of all rivers meet the annual ortho-phosphate environmental quality standard for 'Good' status $(<0.035 \mathrm{mg} / \mathrm{l})$ and Irish rivers have some of the lowest ortho-phosphate concentrations in Europe (Bradley et al, $2015)$. Overall, $53 \%$ of rivers, $43 \%$ of lakes and $93 \%$ of coastal waters were at good or high status during the 2010-2012 monitoring period.

Whilst existing regulations guiding nutrient use on farms are intended to improve water quality nationally, at smaller catchment scales, the impact of specific measures is often more difficult to observe. Further, the impact of changes in nutrient use at field or farm scale is often not observed directly in water quality data due to long nutrient lag times and the interactions of soils and climate. These lag times are defined as water quality responses to changes in land management, depending on the soil characteristics on the farm and across the landscape (Fenton et al., 2011). However, the impact of changes in land management can be difficult to decipher, when weather elements such as rainfall intensity and volume have significant effect on nutrient transfer from terrestrial to aquatic systems. In tandem with statutory instruments to protect surface waters from nutrient enrichment, a number of conservation measures have also been introduced, some of which are part of the Habitats Directive and some are amendments to national policy instruments such as the Fisheries Act ${ }^{11}$. Understanding the landscape setting and the influence of weather patterns will inform how measures and changes to land management will impact on water quality, however there is a need to communicate the benefits of water quality improvements, over and above the environmental impact, such as increased tourism and recreational benefits.

\section{The importance of the ecosystem services provided by water bodies in rural areas}

While agriculture will continue to be the cornerstone of rural areas, the need to generate a second income in order to attract a successor and ensure viability is a reality for most farm families. In this context, farm families across Europe are increasingly undertaking rural or agri-toursim ventures to supplement family farm income for current and future householders.

Fáilte Ireland, the Irish tourist board reported 7.3 million tourists come to Ireland annually, contributing $€ 6.6$ billion to the economy (Fáilte Ireland, 2014) ${ }^{12}$. European tourists account for 2.5 million of these visits each year. In tourism marketing terms, Ireland's unique selling point (USP) is scenery and landscape and a particular activity is a means of enjoying the Irish

\footnotetext{
${ }^{9} \mathrm{https}: / /$ www.agriculture.gov.ie/media/migration/publications/2006/good_ag_practice_handbook.pdf

$10 \mathrm{http}: / /$ www.epa.ie/water/wm/intergratedwater

$11 \mathrm{http}: / /$ www.lawreform.ie/_fileupload/RevisedActs/WithAnnotations/en_act_2010_0010.PDF

12 http://www.failteireland.ie/Research-Insights.aspx
} 
landscape experience. Fáilte Ireland research indicates that enjoyment and exploring of the landscape is the primary motivator for tourists coming to Ireland. Among dedicated walkers Ireland's walking offering is well rated; Ireland has 785 trails and 43 way marked ways in 25 counties. These tourists are largely activity tourists and the research indicates that participants in activity tourism spend $54 \%$ more during their trip and stay $30 \%$ longer than the average tourist. Table 1 presents the main activities in which visitors to Ireland partake.

In tourism terms, "watersports" refers to angling, sailing, kayaking, diving and surfing. Fáilte Ireland and Inland Fisheries research reports show that German and British tourist constitute the greatest market potential for watersports in Ireland, followed by France which has less but still some potential. The Irish domestic market also has high potential with $11 \%$ of the population participating in watersports.

Tab 1. Recreational activities and visitor numbers to Ireland (2014). Source: Fáilte Ireland (2014)

\begin{tabular}{|l|l|}
\hline \multicolumn{1}{|c|}{ Activity } & \multicolumn{1}{c|}{ Visitor numbers } \\
\hline Walking & 1.2 million \\
\hline Cycling & 290,000 \\
\hline Golf & 176,000 \\
\hline Angling & 168,000 \\
\hline Watersports & 86,000 \\
\hline Equestrian & 82,000 \\
\hline
\end{tabular}

The Teagasc Handbook of Rural Tourism suggests that Ireland has a strong tradition of angling and a good reputation (Heneghan et al 2016) and Fáilte Ireland research shows Ireland's angling product as regards 'range of choice' and 'value for money' are voted 'well rated' and 'excellent' by overseas visitors. Of the angling visitors, the majority are from Britain (46\%) and Europe (47\%), with $12 \%$ of anglers coming from France and $11 \%$ from Germany.

Canoeing is the collective term used to describe a wide-ranging sport that encompasses competitive and non-competitive forms of canoeing and kayaking and is also a popular watersports activity for domestic tourists and visitors to Ireland. These recreational activities fall within the remit of examining the benefits of good water quality and including them in catchment characterisations under WFD. Whilst characterisation of catchments and river basin management planning are the planning tools for improving water quality targets, the inclusion of recreational uses of water will provide an economic incentive to meeting targets under WFD.

\section{Economic Valuation of water quality}

Meeting the targets of achieving good ecological status and maintaining high ecological status where it exists, are specific requirements of WFD. There is the broader requirement that calls for an examination of the benefits as well as the costs of improvements in ecological status. In economic terms, water is categorised as a "high exclusion cost" resource due to its liquid, mobile nature. In addition, the lack of property rights means that water is not a highly valued commodity in monetary terms. The distinction between the commodity and environmental benefits derived from water is highlighted by Young (2005), who also notes that estimating the economic value and benefits arising from water-related policies is a difficult task.

Valuations depend on the specific water ecosystem services being valued, along with the water body location and the reason for the valuation (Stithou, 2012) and involves a complex multidimensional process to measure water quality along with several distinct but correlated dimensions (Magat et al., 2000). 


\section{Contingent Valuation}

Of the reasonably limited studies valuing water quality in Ireland, most focus on stated preferences to value water-based leisure activities. Hynes and Hanley (2006) estimated the mean willingness to pay (WTP) of kayakers using a river in Co. Kerry, using a travel cost methodology (TCM). Curtis (2002) also used TCM to estimate the demand for water based activities. In 2009, Hynes et al. found a reduction of $50 \%$ in the recreational value of a river due to water diversion for agricultural use. These studies all relate to estimates relating to recreational use on one specific water body.

\section{Choice Experiments}

An examination of public preferences in relation to improvements in two diverse river environments was undertaken by Stithou (2012). A choice experiment was conducted in the River Boyne catchment in the north east of Ireland and the River Suir catchment in the south east. In general, the study shows that the general public is supportive of improvements in river quality. However, it also reveals that the WTP for improvement is different for each catchment. River Suir catchment respondents are only willing to pay for moderate levels of "River Life" but high levels of improvement in the "Appearance of the River" while River Boyne catchment respondents value all levels of improvement presented. This is further illustrated by the disparity in relation to the value that respondents placed on improvements that would achieve Good Ecological Status. In the River Suir sample, $50 \%$ placed a value of $€ 5$ or less on improvements whereas River Boyne residents had higher values of up to $€ 30$ (Stithou, 2012).

\section{Participation in water based leisure activities}

The largest challenge encountered in estimating the non-market benefits associated with river water quality is the lack of official statistics at sub-national level. Possibly the most comprehensive report on the identification of benefits enjoyed by the general public when it comes to rivers is a research report commissioned by the EPA, undertaken by Howley et al in 2011 . The report was informed by a survey conducted in 2003 by the Economic and Social Research Institute (ESRI) on behalf of the Marine Institute (Marine Institute 2004). The ESRI survey was planned to allow comparison with a previous survey undertaken in $1996^{13}$ (Whelan, 1997). The main objective was to examine the attitudes and behaviours of the population over 16 years of age, toward water based leisure activities.

The ESRI (2003) incorporated phone surveys and questionnaires which were based on the Consumer Sentiment Survey $\left(\mathrm{CSS}^{14}\right)$ and were carried out at the same time each month between April and July of 2003. The sampling procedure initially involved the selection of 50 sampling points from the Electoral Register. For every sampling point, 100 telephone numbers were randomly chosen to complete the 25 interviews required (each survey interview respondent's age, sex and employment was checked in advance of the phone survey.) In order to enable comparison with the wider 1996 ESRI survey, the data were weighted using socioeconomic characteristics of the sample with external population controls (from the Quarterly National Household Budget Survey (Q2 2002 and Q2 2003 ${ }^{15}$ ).

Around 1,200 participants each month were asked about their recreational use of water bodies in the period from April 2002 to June 2003, in relation to:

- Participation in one or more of the 18 listed water based leisure activities (Table 2)

- $\quad$ For each activity, numbers of day and overnight trips were recorded

- Information was recorded in relation to the goals of participation, as well as the duration, cost and number of people involved for overnight trips.

- $\quad$ The costs associated with day trips (equipment, supplies etc.)

- $\quad$ The nature and ownership of vessels used for sailing or boating activities

\footnotetext{
131996 national survey based on water based leisure activities in Ireland

${ }^{14}$ Monthly survey produced by the ESRI and KBC Bank Ireland

${ }^{15}$ http://www.ucd.ie/issda/data/quarterlynationalhouseholdsurveyqnhs/
} 
Tab 2. Survey results for participation in water based recreation activities (2002/2003). Source: Howley et al., (2011)

\begin{tabular}{|c|c|c|c|c|c|c|c|c|c|}
\hline \multirow{2}{*}{ Category } & \multirow{2}{*}{ Activity } & \multirow{2}{*}{$\begin{array}{c}2003 \text { total } \\
\text { participants } \\
\left(000^{\prime} s\right)\end{array}$} & \multirow{2}{*}{$\begin{array}{c}\text { No. } \\
\text { Day } \\
\text { Trips } \\
\text { (000's) }\end{array}$} & \multirow{2}{*}{$\begin{array}{l}\text { Est. No. } \\
\text { Overnights } \\
\text { (000's) }\end{array}$} & \multicolumn{5}{|c|}{$\begin{array}{l}\text { Annual Average expenditure }(€) \text { per participant during overnight } \\
\text { trips }\end{array}$} \\
\hline & & & & & Accommodation & Travel & Other & Total & $\begin{array}{l}\text { Rank } \\
\text { Spend }^{16}\end{array}$ \\
\hline Seaside & $\begin{array}{l}\text { Other trips to } \\
\text { the beach }\end{array}$ & $1,134.60$ & 21,280 & 1,235 & 163 & 25 & 59 & 247 & 5 \\
\hline $\begin{array}{l}\text { Seaside } \\
\text { Trips }\end{array}$ & $\begin{array}{l}\text { Swimming in } \\
\text { the sea }\end{array}$ & 353.5 & 2,779 & 479 & 247 & 29 & 37 & 312 & 2 \\
\hline Boating & Sailing at sea & 58.8 & 606 & 150 & 128 & 10 & 11 & 148 & 10 \\
\hline $\begin{array}{l}\text { Seaside } \\
\text { Trips }\end{array}$ & $\begin{array}{l}\text { Coastal } \\
\text { Nature } \\
\text { Reserves }\end{array}$ & 43.5 & 122 & 23 & 143 & 21 & 16 & 180 & 7 \\
\hline Boating & $\begin{array}{l}\text { Cruising on } \\
\text { inland water }\end{array}$ & 42.8 & 277 & 60 & 152 & 17 & 42 & 211 & 6 \\
\hline $\begin{array}{l}\text { Seaside } \\
\text { Trips }\end{array}$ & $\begin{array}{l}\text { Other trips to } \\
\text { the islands }\end{array}$ & 33.2 & 52 & 51 & 100 & 25 & 34 & 159 & 8 \\
\hline Boating & Boating at sea & 32.1 & 373 & 23 & 244 & 28 & 33 & 304 & 3 \\
\hline Boating & $\begin{array}{l}\text { Boating in } \\
\text { power boats } \\
\text { etc. }\end{array}$ & 24.6 & 212 & 51 & 62 & 12 & 0 & 74 & 15 \\
\hline Watersports & $\begin{array}{l}\text { Water Skiing, } \\
\text { Jet Skiing }\end{array}$ & 19.2 & 160 & 3 & 20 & 13 & 17 & 50 & 17 \\
\hline Watersports & $\begin{array}{l}\text { Surfing, Sail } \\
\text { boarding }\end{array}$ & 17.8 & 180 & 37 & 400 & 91 & 137 & 628 & 1 \\
\hline $\begin{array}{l}\text { Seaside } \\
\text { Trips }\end{array}$ & $\begin{array}{l}\text { Bird } \\
\text { Watching- } \\
\text { coastal }\end{array}$ & 12.4 & 123 & 17 & 184 & 14 & 66 & 264 & 4 \\
\hline $\begin{array}{l}\text { Seaside } \\
\text { Trips }\end{array}$ & $\begin{array}{l}\text { Whale/Dolphin } \\
\text { Watching }\end{array}$ & 9.6 & 17 & 8 & 111 & 19 & 24 & 155 & 9 \\
\hline Watersports & $\begin{array}{l}\text { Scuba Diving, } \\
\text { Snorkelling }\end{array}$ & 9.1 & 117 & 48 & 107 & 19 & 11 & 137 & 11 \\
\hline Watersports & $\begin{array}{l}\text { Other Sea } \\
\text { Sports }\end{array}$ & 7.3 & 26 & 5 & 20 & 7 & 17 & 43 & 18 \\
\hline
\end{tabular}

In general, for the time period 2002-2003, results show that $49 \%$ of the respondents had taken part in water-based leisure activities which generated $€ 434 \mathrm{~m}$ in expenditure (Marine Institute, 2004). For the whole domestic tourism market, the water-based domestic market represents $22 \%$ of total tourism revenue and $45 \%$ of domestic tourism revenue.

Utilising the data from the Marine Institute (2004) survey, Howley et al. (2011) developed indicators of the benefits of 14 water based recreation categories (listed in Table 2) and 4 angling activities (Table 4). The 18 activities are ranked in relation to the size of the "spend" in rural areas accruing from the different activities.

In terms of annual average expenditure per participants, the five highest ranking activities were (in order of spend): surfing \& sail boarding, swimming at sea, boating at sea, bird watching in coastal areas and other trips to the seaside. Two activities, swimming at sea and trips to

${ }^{16}$ Spending is ranked for all water usage i.e. across Tables 2 \& 4 
the seaside, feature as the most popular activities with highest average annual expenditure per participant (Howley et al., 2011).

\section{Watersports}

Howley et al. (2011) further related the Marine Institute (2004) data to Water Management Units as specified within regional River Basin District plans. While largely concentrated in estuarine or coastal waters there are also a number of inland freshwaters which are popular for open swimming and in recent years, the growing popularity of triathlon sporting events has broadened the base of people participating in open water swimming in both coastal and inland water bodies. Howley et al (2011) calculate the total number of participants per WMU by simply adding together the participation rates from both event types (open water swimming and triathlon) across each WMU.

The analysis also found significant regional variation in the distribution of recreational benefits. For example, participants in long distance swim events are heavily concentrated in Dublin and Cork and to a lesser extent Galway. On the other hand, triathlon events are much more evenly distributed across the country. The Moy water management unit in the West of Ireland is by far the most important for recreational angling. When it comes to canoeing and kayaking activity, the analysis indicates that there is a good spatial distribution across the country with a relatively larger number of service providers along the west coast. Cork, Dublin and Galway have the highest number of rowing clubs and events and Dublin City and west Cork (Skibereen/Clonakilty WMU) are popular sailing centres.

Water quality targets under the Bathing Water Directive require all bathing waters to have achieved 'sufficient' status by 2015. Howley et al. (2011) report that monitoring data for the period 2012 to 2015 indicate a high level of compliance with 93\% meeting of Irish bathing waters meeting 'sufficient' water quality in the recent assessment period. Of the water-based recreational activities listed in Tables 2 and 4, Howley et al. (2011) found that the five most popular activities based on highest numbers of participants were seaside trips, open water swimming, fresh water game and coarse fish angling and sea water angling.

\section{Fresh water angling}

Whilst eutrophication of surface water-bodies might not affect the number of participants in activities such as swimming and triathlon events, it could potentially have a greater impact on activities such as fresh water angling, which rely on the ecosystems and species that these waters support. In terms of popularity, fresh water game angling is the third most popular water-based recreational activity in the ESRI study (Marine Institute, 2004). For each participant in the study, the average number of day trips is around 14 days per year, totalling over 1 million day trips (Marine Institute, 2004). In 2012, 58 rivers were open for harvesting, 35 for angling on a catch and release basis only, and 61 rivers were closed $^{17}$.

To enable monitoring of stock levels and to support the establishment of existing conservation measures, a licensing, tagging and log book system is obligatory for everyone who wants to fish salmon and sea trout $(>40 \mathrm{~cm})$ to facilitate evaluation of fish stocks by Inland Fisheries Ireland ${ }^{18}$. For river systems where angling is not allowed or is limited, the estimating of abundance and distribution of salmon is conducted using electro-fishing survey methods.

\section{Salmon Harvest}

As a result of a decline in the number of returning fish and decreased economic returns to commercial licence holders, Ireland undertook a programme of measures between 1996 and 2006 with the objective of transforming its position in relation to the management, development and conservation of salmon and sea trout. In 2007, a complete ban on drift net fishing was implemented. Since 2001, a reduction of $86 \%$ was observed for the Atlantic salmon harvest.

\footnotetext{
$17 \mathrm{http}: / /$ www.fisheriesireland.ie/salmon-regulations-2012-1/197-salmon-and-sea-trout-angling-regulations-2012-1/file

18 http://www.fisheriesireland.ie/Table/Angling-Information/Angling-Information/Page-2.html
} 
Today, angling represents a share slightly over than $54 \%$ of total harvest as against $10 \%$ in 2001 (Inland Fisheries Ireland, 2014).

Table 3 presents catch figures for the Rod \& Line fishing method. The largest catch in the country was recorded on the river Moy (North Mayo), representing $31.8 \%$ of the national total. For commercial fishing, harvesting mostly occurs in estuaries and inshore waters, as opposed to angling methods which preferentially occur in freshwater. The rivers Laune and Feale represent around $50 \%$ of the national total. For the Catch \& Release method, angling is possible in rivers determined by the Conservation of Salmon and Sea Trout Bye-Law. For the period 2009-2010, the river Suir is responsible for $13.4 \%$ of the national total harvest.

Tab 3. Top 5 rivers for salmon harvested or caught for each fishing method. Source: Adapted from Howley et al., (2011)

\begin{tabular}{|c|c|c|c|}
\hline Harvesting Method & River System & No of Salmons & $\%$ of National Total \\
\hline \multirow{5}{*}{ Rod and Line } & Laune & $1,995.10$ & $5.00 \%$ \\
\hline & Feale & $2,058.90$ & $5.10 \%$ \\
\hline & Corrib & $3,048.90$ & $7.60 \%$ \\
\hline & Blackwater (Munster) & $5,004.70$ & $12.50 \%$ \\
\hline & Moy & $12,759.70$ & $31.80 \%$ \\
\hline \multirow{5}{*}{ Commercial } & Owenmore (Bangor) & 1,478 & $7 \%$ \\
\hline & Blackwater (Munster) & 1,872 & $8.90 \%$ \\
\hline & Lower Lee & 2,648 & $12.60 \%$ \\
\hline & Feale & 4,706 & $22.40 \%$ \\
\hline & Laune & 5,170 & $24.60 \%$ \\
\hline \multirow{5}{*}{ Catch and Release } & Ballysadare & $1,625.40$ & $5.40 \%$ \\
\hline & Nore & $2,640.60$ & $8.80 \%$ \\
\hline & Moy & $3,062.10$ & $10.20 \%$ \\
\hline & Blackwater (Munster) & $3,101.70$ & $10.30 \%$ \\
\hline & Suir & $4,017.50$ & $13.40 \%$ \\
\hline
\end{tabular}

Table 4 presents the recreational use survey results for angling activities and illustrates the economic benefit of angling in rural areas. It is evident that the "spend" by anglers is lower than for other water sports (See Table 2), however benefits to rural communities are significant.

While the sustainability of watersports activities in general is largely dependent on "good" water quality and appropriate facilities for visitors and recreational users, it is evident that the sustainability of recreational angling is additionally and critically dependent on the management of sustainable fish yields. 
Tab 4. Survey results for participation in angling activities (2002/2003). Source: Howley et al., 2011

\begin{tabular}{|c|c|c|c|c|c|c|c|c|c|}
\hline \multirow[b]{2}{*}{ Category } & \multirow[b]{2}{*}{ Activity } & \multirow[b]{2}{*}{ 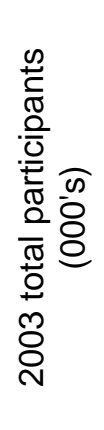 } & \multirow[b]{2}{*}{ 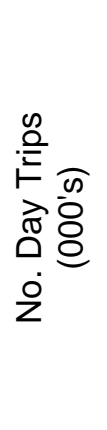 } & \multirow[b]{2}{*}{ 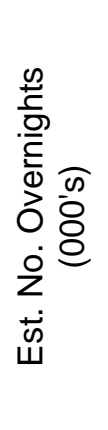 } & \multicolumn{5}{|c|}{$\begin{array}{c}\text { Annual Average expenditure per participant } \\
\text { during overnight trips }\end{array}$} \\
\hline & & & & & 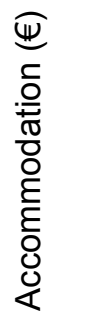 & 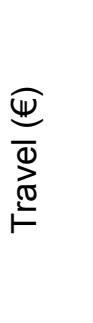 & $\begin{array}{l}\mathbb{\Psi} \\
\bar{\Phi} \\
\stackrel{ \pm}{0}\end{array}$ & $\frac{\mathbb{\Psi}}{\frac{\mathbb{\pi}}{\underline{\pi}}}$ & 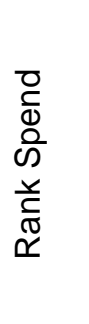 \\
\hline Angling & $\begin{array}{l}\text { Freshwater } \\
\text { Angling for } \\
\text { game fish }\end{array}$ & 80.5 & 1131 & 148 & 70 & 32 & 13 & 116 & 13 \\
\hline Angling & $\begin{array}{l}\text { Sea } \\
\text { Angling } \\
\text { from the } \\
\text { shore }\end{array}$ & 74.1 & 1065 & 47 & 80 & 14 & 24 & 118 & 12 \\
\hline Angling & $\begin{array}{l}\text { Freshwater } \\
\text { Angling for } \\
\text { coarse fish }\end{array}$ & 66.5 & 571 & 72 & 36 & 39 & 12 & 87 & 14 \\
\hline Angling & $\begin{array}{l}\text { Sea } \\
\text { Angling } \\
\text { from boat }\end{array}$ & 53 & 338 & 32 & 40 & 10 & 13 & 62 & 16 \\
\hline
\end{tabular}

\section{Participatory approaches to engage communities in the protection of water quality}

The WFD attaches considerable importance to public participation. Irish examples of community engagement and public participation includes initiatives such as Duhallow LIFE ${ }^{19}$, a 1.9 million euro conservation and restoration project co-financed by EU commission and the Irish government. This project actively engaged the farming community along the Allow River in Cork to implement practical measures such as fencing riparian areas to restrict livestock access and prevent bankside erosion. The process adopted here has embraced the concept of integrated catchment management by increasing awareness and including community groups and schools in addition to the farming community, to participate in finding solutions to protect water quality in their catchment. Other examples include the Mulkear LIFE ${ }^{20}$, Kerry LIFE ${ }^{21}$ and Aran LIFE ${ }^{22}$ projects with similar objectives to restore and/or protect endangered species through protection of water quality.

The new Integrated Catchment Management approach to river basin management, under the second phase of the WFD is dependent on a high level of public participation. This public participation can be organised by non-governmental organisations such as Rivers Trusts who work with the Local Authorities, or by the Local Authorities themselves. Rivers Trusts show communities how they can become more involved in protecting and enhancing their local river catchment $^{23}$. For example, in Co. Kerry, the Maigue Rivers Trust structure is comprised of 11 directors who represent a variety of interests that include: angling, farming, community and

\footnotetext{
19 http://duhallowlife.com/

20 http://mulkearlife.com/

$21 \mathrm{http}: / /$ kerrylife.ie/

22 http://www.aranlife.ie/

23 http://www.ringofgullion.org/events/talk-rivers-trusts-waters-communities-river-fane/
} 
local development, business, tourism/outdoor/leisure pursuits, education, research (biology), finance, elected representatives and those with an interest in conservation and wildlife.

The Teagasc $^{24}$ (2013) submission to the public consultation on the Rural Development Programme for Ireland (RDP) 2014-2020 suggested that additional support is needed to expand the current cross compliance Farm Advisory Model (FAS) to support competitiveness and broader sustainability issues in addition to the current cross compliance remit. In particular, the submission from Teagasc reported that there was a need for "faster transfer of knowledge from research and expanded Farm Advisory Service (FAS) requirements to practical farming" (p.60). In addition, Teagasc highlighted the important role of advisors in achieving cross compliance on farms, while the organisation also criticised the cross compliance policy focus on audit and penalty, while according to the submission, the "potential role of education and information support has been left completely out of the equation" (p. 60).

Frequently when we design interventions, we focus on one segment of the value chain, or one part of the value chain responds to the demand. As a multi-scheme, multi-objective and multistakeholder programme, the RDP is complex requiring a variety of different knowledge transfer mechanisms targeted at different types of stakeholders. An innovation system approach looks at the system of those used in applying a particular area of knowledge to a problem or an objective. These for example combine, farmer, entrepreneur or community or others in the value chain with researcher, extension or development officer, other rural professionals and agencies.

\section{Social Learning}

A participatory approach that is becoming more and more popular in recent years is the concept of social learning as posited by Bandura (1963) in which learning is a cognitive process that takes place in a social context and can occur purely through observation or direct instruction. In the context of the EU Water Framework Directive, Pahl Wostl $(2007,2009)$ applied the concepts of social learning to the challenges of water quality. According to Ó Cinnéide (2015), "social learning can be a powerful ingredient of change" and "social learning is intensified when stakeholders with different perceptions come together and engage with each other." Ó Cinnéide (2015) further notes that when principles of social learning \& interactive governance are embedded, stakeholders are more likely to work together in water management and that social learning by state, communities and non-state actors is key to the future governance of water resources, flood plains and climate change in the $21^{\text {st }}$ century.

\section{The Irish Experience}

The experience of many Local Authorities in Ireland in implementing water quality regulations is that lack of awareness is a barrier to better water management. O'Flaherty (2015) cites a "Wise Use of Floodplains" project officer in Co. Monaghan as stating that "a period of education and information is needed to increase awareness, build relationships, break down barriers and lead to participation".

O'Flaherty (2015) describes how Monaghan Local Authority had realised over a number of years that funding alone was not enough to get communities to engage - the problem stemmed from a general lack of awareness of water issues. Thus the Local Authority assisted Tanagh Outdoor Education Centre to develop an aquatic ecology activity day - suitable for community groups and school groups. Workshops and local maps were developed to 'tell a story' about the local river. The experience of the project however, was that engaging farmers posed a challenge. One community organiser (a farmer) commented that 'the people we needed at the river did not come'. The views of local farmer representatives were that...."sustainability is important but so is profitability"......"farmers are dealing with....increasing regulation, volatile markets, farm viability issues and multi-nationals.....therefore making water quality meaningful is difficult"......"we need to re-connect people with their local waterways"......."we have work to do..... to make issues meaningful we need to link community, culture, heritage, tourism, recreation..... and water management (O'Flaherty, 2015).

\footnotetext{
24 The Agriculture and Food Development Authority
} 


\section{Experiences in other countries}

In Sweden, the Federation of Swedish Farmers (LRF) has taken a strong role in water quality management in agriculture. Farmers are encouraged to establish wetlands as a nitrogen and phosphorus trap. These wetlands have the added bonus of providing additional biological diversity. Buffer zones along water courses have become a common feature and there are now around 10,000 km in Sweden, equivalent to one-quarter of the Earth's circumference.

Ó Cinnéide (2015) presents a case study of a spectrum of interviews with stakeholders in four EU states which have different approaches to water management: Ireland \& Scotland which employ the classic "command and control" approach, as against the models of governance employed in Sweden \& Finland, which have long traditions of civic engagement.

In Sweden, the main farming organisation (LRF) and Swedish forest owners are active players in the water management arena, the LRF report that "it's the only way really, to be involved. If you don't get the farmers' knowledge, you won't have the right measures and the right solutions" (LRF). ${ }^{25}$ Ó Cinnéide (2015) concludes that the Swedish rural culture facilitates a platform for both formal and informal interactions, building a social learning model.

In Finland, the farming organisation (MTK) \& Nature Conservation are active contributors in relation to stakeholder engagement on water quality. MTK report that there are recurring issues of trust and transparency among WFD participants... "They are making rules that are binding on farmers and we are worried that they are biased" (MTK rep)..."What is the real effect of these Measures - can we see it somewhere?" Overall, Ó Cinnéide (2015) finds evidence of social learning at both horizontal (policy) \& vertical levels.

In Scotland, the Scottish EPA (SEPA) engaged with the engaged with the National Farmers Union (NFU) on the issue of diffuse pollution of water from agricultural practices. They used local champion farmers to deliver the messages and local NFUs to get farmer engagement for outreach events. The engagement resulted in clear evidence of a vertical learning approach to the WFD and a consensus among farmers: "ok, we have a problem - we need to do something here" (Ó Cinnéide, 2015).

In the Irish case, Ó Cinnéide (2015) reports that earlier social learning from River projects was not reflected in the 2003 WFD structures: "it fell away. We didn't have the resources. We were just surviving!" Ó Cinnéide (2015) concludes that the learning withered due to rigid structures, an over-dependence on RBD consultants \& a lack of continuity which eroded the potential for social learning in the first cycle of the WFD.

\section{Discussion and conclusions}

Irish rivers, lakes and coastal waters provide significant market and non-market benefits that are spatially distributed across the Republic of Ireland. Water Quality is one amongst a number of factors that determine the range of benefits enjoyed by the general public and current statutory instruments and conservation measures aimed at protecting water quality and freshwater ecosystems will ensure that water for recreational use continues to grow in popularity.

In relation to the protection of water quality in rural areas, there are many potential win-wins for the environment, for farmers, for tourists and for local communities. However, experience of participatory actions on the ground indicate that there can be a disconnect between water quality policy objectives as put forward in the WFD and their implementation at ground level. In Ireland until now, attempts to protect water quality have been focused on actions directed largely at farmers. This paper also looks at water quality in rural areas from a different perspective i.e. recreational use. However, while the objectives of both sectors are common, there may be lost opportunities in relation to connecting or re-connecting farmers and rural dwellers with the issues and challenges associated with aquatic environment in their areas. Are farmers aware of

\footnotetext{
25 http://www.google.ie/url?sa=t\&rct=j\&q=\&esrc=s\&source=web\&cd=1\&ved=0ahUKEwjkoZz16nNAhVaOMAKHRJBC0gQFgggMAA\&url=http\%3A\%2F\%2Fwww.balticdeal.eu\%2Fdocuments\%2Fwater-qualitymanagement-in-sweden\%2F\%3Faid\%3D6266\%26sa\%3D1\&usg=AFQjCNGds_cA17QhAbQh8lumZ3Qj921vcA
} 
the recreational ecosystem value of having "good" water quality? Equally, are communities aware of the restrictions placed on farm management practices in relation to water quality objectives?

Research undertaken in Ireland by Teagasc has demonstrated that there are many opportunities to avoid lose-win solutions, where water quality actions are linked to lower farm incomes. However the technical detail of the solutions may be difficult for stakeholders to understand. There is therefore a need for greater farmer engagement and education, particularly in win-win options in relation to water quality mitigation measures that improve the environment in general and water quality specifically while also improving farm incomes and the potential for rural tourism. There is also a greater need for the integration of farmers, rural tourism providers and local communities in participatory approaches to disseminating messages in relation to the importance of water quality to agriculture, to the wider environment and to tourism in rural areas, in the context of ensuring and promoting sustainable natural resource use and ecosystem service provision in rural areas.

At policy level, there is now a greater awareness of the importance of water quality in rural environments in the administration of agri-environmental schemes in Ireland introduced under CAP, which now provide priority access to the farming community within areas of pristine water quality, or high status areas. However if we are serious about using a social learning perspective as an approach to driving forward a high standard of water quality in Ireland, all sections of the agriculture sector from farmers to academic researchers must be willing to work and learn together to decide what actions are needed for agriculture to remain sustainable and allow for wider societal enjoyment of the waters in the catchment. This will require both integrated thinking and strategic compromises.

\section{References}

[1] Aylward, B., Bandyopadhyay, J. \& Belausteguigotia, J. C., eds. (2005). Freshwater Ecosystem Services. In: Ecosystems and Human Well-being; Policy Responses (pp. 213256). Washington, D.C.: Island Press.

[2] Bandura, A. (1963). Social learning and personality development. New York: Holt, Rinehart, and Winston.

[3] Barnes, A., Toma, L., Willock, J. \& Hall, C. (2013). Comparing a 'budge' to a 'nudge': Farmer responses to voluntary and compulsory compliance in a water quality management regime. Journal of Rural Studies 32, 448-459. DOI: 10.1016/j.jrurstud.2012.09.006.

[4] Bartolini, F., Gallerani, V., Raggi, M. \& Viaggi, D. (2012). Modelling the Linkages between Cross-Compliance and Agri-Environmental Schemes Under Asymmetric Information. Journal of Agricultural Economics 63(2), 310-330. DOI: 10.1111/j.1477-9552.2012.00339.x.

[5] Boccaccio, L., Hegarty, J. \& Brunner, A. (2009). Through the green smokescreen: how is CAP cross compliance delivering for biodiversity? Cambridge: Birdlife International.

[6] Bradley, C., Byrne, C., Craig, M., Free, G., Gallagher, T., Kennedy, B., Little, R., Lucey, J., Mannix, A., McCreesh, P., McDermott, G., McGarrigle, M., Ní Longphuirt, S., O’Boyle, S., Plant, C., Tierney, D., Trodd, W., Webster, P., Wilkes, R. \& Wynne, C. (2015). Water Quality in Ireland 2010-2012. Wexford: Environmental Protection Agency.

[7] Crowley, E. (2003). The evolution of the Common Agricultural Policy and social differentiation in rural Ireland. Economic and Social Review 34(1), 65-86.

[8] Curtis, J. A. (2002). Estimating the demand for salmon angling in Ireland. Economic and Social Review 33 (3), 319-332.

[9] Daly, K., Mills, P., Coulter, B., McGarrigle, M., 2002. Modeling phosphorus concentrations in Irish rivers using land use, soil type, and soil phosphorus data. Journal of Environmental Quality 31, 590-599. 
[10] Dworak, T. (2007). The role and significance of voluntary agri-environmental advisory services in minimising water pollution from the agricultural sector. Agri-environmental extension services around the Baltic Sea, Riga, Latvia, 6-7 Dec 2007.

[11] Fáilte Ireland. Determination of Waters of National Tourism Significance and Associated Water Quality Status. 2007. National Tourism Development Authority.

[12] Fenton, O., Schulte, R. P. O., Jordan, P., Lalor, S. T. J. \& Richards, K. G. (2011). Time lag: a methodology for the estimation of vertical and horizontal travel and flushing timescales to nitrate threshold concentrations in Irish aquifers. Environmental Science \& Policy. 14(4), 419-431. DOI: 10.1016/j.envsci.2011.03.006.

[13] Hart, K., Farmer, M., Baldock, D., Brouwer, F., Fox, G. \& Jongeneel, R. (2012). The role of cross compliance in greening EU agricultural policy. In Brouwer, F., Fox, G. \& Jongeneel, R., eds. The Economics of Regulation in Agriculture: Compliance with Public and Private Standards (pp. 9-28). Wallingford: CABI.

[14] Heneghan, M, Caslin, B., Ryan, M. \& O'Donoghue, C. (2016). Teagasc Rural Tourism Handbook. Teagasc Rural Economy and Development Programme. Carlow: Teagasc Oak Park.

[15] Hodge, I., Hauck, J. \& Bonn, A. (2015). The alignment of agricultural and nature conservation policies in the European Union. Conservation Biology 29(4), 996-1005. DOI: $10.1111 /$ cobi.12531.

[16] Howley, P., Buckley, C., Jordan, R., O'Donoghue, C., Hynes, S. \& Green, S. (2011). Sustainable management strategies: Identifying the non-market benefits of rivers and the major factors affecting river water quality across the Republic of Ireland. Washington, D.C.: U.S. Environmental Protection Agency.

[17] Hynes, S. \& Hanley, N. (2006). Preservation versus development on Irish rivers: Whitewater kayaking and hydro power in Ireland. Land Use Policy Journal 23(2), 170-180. DOI: 10.1016/j.landusepol.2004.08.013.

[18] Inland Fisheries Ireland, 2014. Wild Salmon and Sea Trout Statistics Report. http://www.fisheriesireland.ie/fisheries-management-1/608-wild-salmon-and-sea-troutstatistics-report-2014/file.

[19] Kristensen, L. \& Primdahl, J. (2004). Potential for environmental cross-compliance to advance agri-environment objectives. [Report of Seminar 3 EU Concerted Action Project "Developing Cross-compliance in the EU-Background, Lessons and Opportunities]. Copenhagen: The Royal Veterinary and Agricultural University.

[20] Magat, W. A., Huber, J., Viscusi, W. K. \& Bell, J. (2000). An iterative choice approach to valuing clean lakes, rivers and streams. Journal of Risk and Uncertainty 21(1), 7-43. DOI: 10.1023/A:1026565225801.

[21] Marine Institute, 2004. A National Survey of Water-Based Leisure Activities in Ireland 2003 http://oar.marine.ie/bitstream/10793/885/1/SurveyofWaterBasedLeisureActivities/reland.pdf

[22] Mellander, P.-E., Melland, A. R., Jordan, P., Wall, D. P., Murphy, P. N. C., Shortle, G. Quantifying nutrient transfer pathways in agricultural catchments using high temporal resolution data. Environmental Science \& Policy 24 (2012), 44-57.

[23] Menghi, A., de Roest, K., Porcelluzzi, A., Deblitz, C., von Davier, Z., Wildegger, B., de Witte, T., Strohm, K., Garming, H. \& Dirksmeyer, W. (2008). Assessing farmers' cost of compliance with EU legislation in the fields of environment, animal welfare and food safety [Final Report]. Brussel: EC Directorate General for Agriculture and Rural Development.

[24] Mills, J., Gaskell, P., Reed, M., Short, C., Ingram, J., Boatman, N., Jones, N., Conyers, S., Carey, P., Winter, M. \& Lobley, M. (2013). Farmer attitudes and evaluation of outcomes to on-farm environmental management. [Report to Department for Environment, Food and Rural Affairs]. Gloucester: Countryside and Community research Institute. 
[25] Murphy, P., Plunkett, M. \& Wall, D. (2014). Soil Fertility Atlas of Ireland. Carlow: Teagasc.

[26] Ó Cinnéide, M. (2015). Social Learning and the Agricultural Sector - the Water Framework Directive in Ireland, Scotland and Scandinavia [unpublished presentation] Catchment Science 2015. Wexford. 28th September, 2015.

[27] O'Flaherty, B. (2015). Community engagement in water management - a local authority experience [unpublished presentation]. TIMe Workshop, Dundalk Institute of Technology. Nov 2015. Monaghan County Council.

[28] Pahl-Wostl, C. (2007). Transition towards adaptive management of water facing climate and global change. Water Resources Management. 21(1), 49-62. DOI: 10.1007/978-1-40205591-1_4.

[29] Povellato, A. \& Scorzelli, D. (2006). The Farm Advisory System: A Challenge for the Implementation of Cross Compliance. [Deliverable D14 of the CC Network Project. SSPE-CT-2005-022727].

[30] Roberts, W., Doody, D., Gonzalez, J, Jordan, P. and Daly, K. (2017). Assessing the risk of phosphorus transfer to high ecological status rivers: Integration of nutrient management with soil geochemical and hydrological conditions. Science of the Total Environment. 589, 25-35.

[31] Roberts, W., Fealy, R., Doody, D., Jordan, P. and Daly K. (2016). Estimating the effects of land use and environmental characterisitcs on high ecological status in Irish rivers at different scales. 2016. Science of the Total Environment. 618-625.

[32] Seale, C. (2014). Cross-Compliance - Improving Farmer Engagement [unpublished presentation] National Agri Environment Conference. Thursday, 13th November, 2014, Tullamore Court Hotel, Co. Offaly.

[33] Stoate, C., Báldi, A., Beja, P., Boatman, N., Herzon, I., Van Doorn, A., De Snoo, G., Rakosy, L. \& Ramwell, C. (2009). Ecological impacts of early 21 st century agricultural change in Europe-a review. Journal of Environmental Management 91(1), 22-46. DOI: 10.1016/j.jenvman.2009.07.005.

[34] Teagasc (2013). Teagasc submission on the Rural Development Programme for Ireland (RDP) 2014-2020, Public Consultation. Teagasc, Athenry, Co. Galway, Ireland http://www.teagasc.ie/publications/2012/3132/RDP_2012.

[35] Stithou, M. (2012). The Economic Value of Improvements in the Ecology of Irish Rivers due to the Water Framework Directive [PhD Thesis]. University of Stirling.

[36] Varanka, S. \& Luoto, M. (2012). Environmental determinants of water quality in boreal rivers based on partitioning methods. River Research and Applications 28(7), 1034-1036. DOI: $10.1002 /$ rra. 1502.

[37] Whelan, B. J. (1997). A National Survey of Water-Based Leisure Activities, Ireland [Research Report]. Dublin: Marine Institute.

[38] Woli, K. P., Hayakawa, A., Kuramochi, K. \& Hatano, R. (2008). Assessment of river water quality during snowmelt and base flow periods in two catchment areas with different land use. Environmental Monitoring and Assessment, 137(1-3), 251-260. DOI: 10.1007/s10661007-9757-4.

[39] Young, R. A. (2005). Determining the economic value of water: concepts and methods. Resources for the Future. London: Routledge. 